\title{
Hope and Irony
}

\section{A Comparative Study of the Philosophies of Richard Rorty and Jonathan Lear}

\author{
Kresten Lundsgaard-Leth
}

Assistant Professor, Dept. of Learning and Philosophy, Aalborg University kll@learning.aau.dk

\begin{abstract}
This article looks into the phenomena of irony and hope as well as their relation. The article starts out with an analysis of Richard Rorty's understanding of private irony and social hope. Here, I argue the case that Rortarian irony is not primarily a matter of epistemic skepticism but instead an existential stance meant to deal appropriately with the idiosyncratic nature of one's private projects. Moving on, the article focuses on Jonathan Lear's depiction of two peculiar instances of two phenomena: radical hope and ironic disruption. Whereas radical hope is the experience of hope in a crisis situation where all meaning — and thus every reason to act — has been lost, the experience of ironic disruption accentuates the constitutive instability and openness of the practical identities we inhabit. Insofar as Rorty cannot account for these phenomena, Lear's analyses present a serious challenge to Rorty's neo-pragmatic philosophy.
\end{abstract}

\section{Keywords}

Hope - irony - Rorty - Lear - pragmatism - practical identity

A considerable number of the most influential thinkers in the history of Western civilization have thought extensively about both hope and irony without all too often getting into a substantial consideration about the possible relation (and difference) between the two phenomena. Hegel, for his part, argues quite unmistakably against both irony and hope. ${ }^{1}$ The notorious enfant

1 In his Grundlinien der Philosophie des Rechts, Hegel more than once explicates, how "mere hope" is virtually opposed to the "concrete" normativity of ethical life. Moreover, irony is 
terrible of philosophy, Nietzsche, is - as one might have expected-far more ambivalent regarding both notions, although they seem to be of equal importance to him. ${ }^{2}$ To mention just a few others, the younger Thomas Mann favors a specific form of literary irony over the lameness of humanistic hope, while a contemporary thinker and dialectical materialist such as Slavoj Žižek mutatis mutandis prefers the radical hope of conceptually updated Marxism to theas he sees it-lameness of liberal irony. ${ }^{3}$

And then there is Richard Rorty. Rorty's position concerning these matters is probably best explained through his Dewey-inspired "distinction between the private and the public."4 Or to be more precise: a division between the (oftentimes) idiosyncratic irony of private individuals as opposed to the solidary hope of liberal citizens in a (re)public(an) community. In the end, it is Rorty's explicit ambition to reconcile private irony with liberal hope, although he is just as explicit about wanting to de-metaphysize any attempt to-through, e.g. positive science or rational philosophy - prove the necessity of any such reconciliation let alone give any epistemic justification whatsoever hereof. ${ }^{5}$ In Rorty's own vocabulary, ${ }^{6}$ the compatibility of irony and hope can—and must—be argued for on a thoroughly "contingent" footing.

heavily excoriated as nothing less than the "highest form" of evil itself (cf. e.g. Georg Wilhelm Friedrich Hegel, Grundlinien der Philosophie des Rechts (Frankfurt am Main: Suhrkamp, 1986), 239 and 277-86).

2 To be sure, Nietzsche's attitude towards irony and hope is primarily of a critical character, e.g. in Nietzsche's second “Untimely Mediation” from 1874, Vom Nutzen und Nachteil der Historie für das Leben. His later books such as Zur Genealogie der Moral and Also Sprach Zarathustra, nonetheless offer themselves to the reader as an attempted orchestration of a positive vision of "new hopes" (cf. e.g. Friedrich Nietzsche, Zur Genealogie der Moral-eine Streitschrift (Köln: Anaconda Verlag, 2006), 313 and Friedrich Nietzsche, Also Sprach Zarathustra (Köln: Anaconda Verlag, 2005), 242).

3 Cf. e.g. Thomas Mann, Betrachtungen eines Unpolitischen (Frankfurt am Main: Fischer Taschenbuch Verlag, 2009), 47 and Slavoj Žižek, First as Tragedy, then as Farce (London: Verso Books, 2009), 77-88.

4 Richard Rorty, Contingency, Irony, and Solidarity (Cambridge: Cambridge University Press, 2008a), 83 .

5 Rorty, Irony, 79 and 141.

6 I do not mean to be unnecessarily elaborate, but it is actually very much in the spirit of Rorty himself to determine his vocabulary as just that (i.e. a "vocabulary" among others rather than some universal meta-language of truth-conditioners). 
But what does Rorty hereby mean to argue, and by what discursive means? Let me attempt an answer to this question by paraphrasing the title of one of Rorty's books. This move will allow us to expose critical distinctions in his authorship amongst what we shall introduce as (i) epistemic contingency, (ii) existential irony and (iii) social hope, which runs through virtually all of Rorty's writings. ${ }^{7}$ Allow me to briefly sketch these three conceptual configurations:

Rorty's case for epistemic contingency is a deliberate deflation of especially two perspectives that have traditionally thrived amongst philosophers, namely the dualistic perspective of Platonism and the tendency towards positivistic scientism in much of modern thinking. ${ }^{8}$ Rorty argues that Platonic dualism and modern scientism-despite their obvious differences-share the presupposition that their view on things has somehow access to the essential structure of how the world "really is." ${ }^{\prime 9}$ Or as he also coins it: both traditional philosophy and contemporary followers of the scientistic worldview lay claim to knowing the objective Truth (with a capital T) about the world. As it is, Rorty's critique is not completely unwarranted. The "idea" is simply truer than the mere "phenomenon" if (Plato's) Socrates in The Republic has his way..$^{10}$ And quite a few scientists actually do uphold the idea that quantifiable properties of elementary particles are both epistemically truer and ontologically more objectively real than social relations as investigated by the human sciences let alone the mere qualities of subjective experience. ${ }^{11}$ Insofar as a large portion of contemporary analytical philosophy seems to be both metaphysical in Plato's sense and scientistic in for instance David Lewis' sense, we hardly need to go into detail about the fact that Rorty does not hold these disciplines in high esteem. ${ }^{12}$ In Rorty's opinion, the strongest claims of Truth-discourses

7 Obviously, I am here thinking of Rorty's rather well-known Contingency, irony, and solidarity. I translate "solidarity" into "hope," which I also believe to be the metaphorical move of the later Rorty himself.

8 Cf. ibid., 3, and Richard Rorty, Philosophy and Social Hope (London: Penguin Books, 1999), xii ff.

$9 \quad$ Cf. ibid., 51.

10 To be precise, the idea is nothing but the truth of the phenomenon. A good deed is only good insofar as it is a partaking instantiation of the "Idea of the Good" (cf. Plato, Staten (Copenhagen: Museum Tusculanums Forlag, 2003), 507b ff.

11 Cf. Rorty, Social Hope, 175 ff. For an interesting meta-ontological defense of the notorious "primary qualities" of British empiricism, see Quentin Meillassoux, After Finitude An Essay of the Necessity of Contingency (New York: Continuum, 2009), 1-27.

12 In an anthology celebrating the $100^{\text {th }}$ birthday of Hans-Georg Gadamer, Rorty states the following about what he thinks of as the unholy alliance of positivism and (ratio-centric) 
ultimately boil down to nonsensical phantasms. From Rorty's point of view, there are a couple of reasons as to why this is the case: firstly, there is no truth without "truth conditions" (i.e. both socially and epistemically stable criteria for truth-apt sentences). Secondly, and more importantly, there just do not exist any meta-linguistic, not to mention transcendental, truth conditions outside of language which can meaningfully be understood to condition truth inside of each language game (or "vocabulary"). ${ }^{13}$ Thirdly, without any such universal truth conditions, we can no longer entertain the idea that we are able to describe the true objectivity of the world sub species aeternitatis. In Thomas Nagel's terminology, there are merely points of view from "somewhere." And to stay within this vocabulary: the alleged point of view from nowhere is simply a bad view from somewhere, as Rorty would have it:

[T] he vocabulary in which the traditional problems of Western philosophy were formulated were useful at one time, but are no longer useful $[\ldots][W] e$ have different purposes [now], which will be better served by employing a different vocabulary [...] We pragmatists cannot make sense of the idea that we should pursue truth for its own sake. ${ }^{14}$

A lot is going on in this passage that must be clarified if one wishes to get to the core of the Rortarian project. In characteristic fashion, Rorty does not spend too much time arguing epistemologically against epistemic necessity. Instead, Rorty effectively pulls himself out of the language game of representationalism and transcendentalism, respectively, favoring instead the idea of every language game as a cultural contribution to the "maturation of our concepts," simply in

dogmatism: "Es gibt im Bereiche der analytischen Philosophie viele hervorragende Theoretiker [...], die sich unerschrocken für eine physikalistische Metaphysik einsetzen [...] Nach ihrer Meinung liefert die Naturwissenschaft Erkenntnisse über Wesenheiten und Notwendigkeiten, die [...] nicht nur de dicto, sondern de re gelten" (Richard Rorty, "Sein, das verstanden werden kann, ist Sprache," in »Sein, das verstanden werden kann, ist Sprache«, ed. Rüdiger Bubner (Frankfurt am Main: Suhrkamp, 2001), 32, my italics).

13 Cf. e.g. Richard Rorty, "Response to Donald Davidson" in Rorty and his Critics, ed. Robert Brandom (Malden: Blackwell Publishing, 2008b), 73 ff. and Richard Rorty, Philosophy as Cultural Politics - Philosophical Papers, Volume 4 (Cambridge: Cambridge University Press, 2007), 91. It is not even the case that one plus one always equals two (outside of mathematics). Put two drops of water together, and you still get just one drop of water. Cut (most) living creatures in half, and you do not get two halves of a living — but of a dead—one. The potential examples are legion.

Rorty, Social Hope, xxii-xxv, my italics. 
order to make us "happier, freer, and more flexible."15 In this vein, thinking has to justify its endeavors in terms of its cultural usefulness rather than its epistemic truthfulness. Philosophically, this essentially has to be the case for Rorty, because for him - as we have already explicated - there simply are no truths beyond the perspective of limited, historically finite vocabularies, wherefore the validation of any given vocabulary should be conceptualized as being a matter of its extrinsic consequences rather than some-illusionary-intrinsic value. To paraphrase once more the above standing quotation, it simply does not make sense for pragmatists of the Rortarian school to follow something that is not even there, namely Truth with a capital T, for "its" own sake.

But what are the different purposes that Rorty invokes, and to which should we allegedly employ "a different vocabulary"? As we shall see, answering this question will allow us to elaborate on precisely the phenomena of existential irony and social hope. Rorty himself delineates the concept of irony in the following manner:

I shall define an "ironist" as someone who fulfills three conditions: (1) She has radical and continuing doubts about the final vocabulary she currently uses ${ }^{16}[\ldots] ;$ (2) she realizes that argument phrased in her present vocabulary can neither underwrite nor dissolve these doubts; (3) insofar as she philosophizes [...] she does not think that her vocabulary is closer to reality than others. ${ }^{17}$

As is obvious, Rorty's notion of irony depends to a large extent on his understanding of the constitutive contingency of epistemic quarrels. If one agrees on calling Rorty a meticulous skeptic with regard to necessary truth(s) — and I have tried to argue that one should surely agree to this-one ought probably also to adopt Michael Williams' conviction that Rortarian "irony is [epistemic] skepticism by another name."18 Importantly, however, it is not that simple. Williams certainly has a specific point of some validity but his conflation of the two concepts nonetheless suffers from a certain — and very crucial—blind spot. As it is, there has to be made a qualified distinction between the epistemic nature of Rorty's contingency-discourse and the much more existential character

15 Rorty, Cultural Politics, 124.

16 A "final vocabulary" in Rorty's sense is the fundamental, highly implicit (not amenable to being made explicit), and defining vocabulary in and through which each person is attempting to lead a meaningful existence.

17 Rorty, Irony, 73, my italics.

18 Michael Williams, "Epistemology and the Mirror of Nature" in Brandom, Critics, 210. 
of his understanding of irony. As such, Williams' claimed identity between skepticism and irony quite simply overstates the epistemic aspect of the phenomenon of irony. In short, Williams' interpretation is too epistemic. ${ }^{19}$ Instead of subscribing to Williams' confusion of epistemic and existential irony, I want to stress that Rorty believes that it is one thing to understand the contingency of our final vocabularies and another matter entirely how one chooses to live with this understanding. And what ultimately matters most to Rorty is indubitably the second part of this equation. ${ }^{20}$

To put it in other words: Rorty clearly prioritizes practice over theory. However, the decisive part of this - at least nowadays - more or less typical hierarchy is not so much the hierarchy in itself as it is Rorty's consequent bisection of its former component: a bisection, as it is, of the practical domain into existential irony and social hope. But how are we to understand this difference in detail?

On our reading, Rorty's actual use of the word "irony" is not entirely clearcut. The meaning of Rortarian irony becomes much clearer as soon as one distinguishes consistently between its epistemic and its practical features. Regarding the epistemic part, both public hope and private irony are indisputably "ironical," that is: both of them accept contingency as a condition for human knowledge - and for the human condition altogether. ${ }^{21}$ In this vein, both of them favor conversation over analysis as well as literary metaphors over philosophical principles. ${ }^{22}$ And indeed: these priorities are in

19 On this interpretation, the primarily epistemological character of the predominant tendency in the Anglo-American readings of Rorty is both analytically misguided and somewhat exegetically worrisome. To illustrate this point, the "Index" of a critically acclaimed anthology such as Rorty and his Critics only indicates one single use of the notion of "hope" and three instances of "irony" as opposed to for instance 17 hits on different variations of "causality" or "causation" (cf. Brandom, Critics, 399-400).

20 Obviously, there is a palpable connection between how we understand the world and how we choose to live in it. Nonetheless, one can easily advocate the contingency of knowledge in principle and continue (or begin) to live like for instance a self-assured egoist with political sympathy for dictatorship in practice. Rorty explicitly admits to being in favor of epistemological rather than ethical disagreements. When it comes to the most important questions (i.e. ethical ones) he thus writes: “we don't [even] have a philosophical argument, we just have an appeal to American [??] common sense" (Rorty, Social Hope, 107).

21 This is clearly one sense in which Rorty uses "irony." As an example, his infamous talk of "liberal ironism" is only understandable along these lines (cf. e.g. Rorty, Irony, 91 and James Conant, "Freedom, Cruelty, and Truth: Rorty versus Orwell" in Brandom, Critics, 310-15). 
fact constitutive parts of one of irony's characteristics. Nonetheless, Rorty also explicitly sets out to defend a specified, private "ironism" that is not only epistemologically contingent, but also idiosyncratically educating ${ }^{23}$ in such a way that it "seem[s] to me [i.e. to Rorty himself] invaluable in our attempt to form a private self-image, but pretty much useless when it comes to politics." 24 With this sentence, and others much like it, we have a strong case suggesting an interpretation that distinguishes (within the realm of the practical) quite sharply between the epistemic features of liberal irony in general and the more specific existential nature of private irony. ${ }^{25}$ What makes Rorty's idea of something invaluable - albeit at the same time politically useless - in the private use of existential irony comprehensible is nicely conceptualized by Jürgen Habermas, when the latter endeavors to explain Rorty's position through the notion of complementarity. In my opinion, Habermas is simply dead-on in his characterization of Rorty's distinction between the private and the public as both a differentiation and reconciliation between what Habermas coins the esthetical and the political. ${ }^{26}$ To illustrate this: I, on the one hand, can privately hope to witness an epic staging of Wagner's Parsifal, which can potentially challenge my self-development (or simply be for my personal entertainment); while I (or we), on the other hand, can - in the words of Rorty - hope "that someday we shall be willing and able to treat the needs of all human beings with the respect and consideration with which we treat the needs of those closest to us, those whom we love."27 It should not be too difficult to grasp the primacy of the esthetical in the Wagnerian example as opposed to the much more socio-political aspiration of Rorty's hopeful love-analogy. These two different hopes are simply motivated in different ways.

23 Or "edifying," as Rorty sometimes coins it (cf. Rorty, Mirror, 357-72).

24 Rorty, Irony, 83, my italics.

25 As will be obvious, private irony is also epistemologically "ironic," as indeed every belief should be (because everything is ultimately contingent), according to Rorty. Or to flesh out the same point in an inverted — and more Rortarian — fashion: as there is no way of knowing how the world ultimately is, we are best off being epistemologically ironic at all times.

26 Habermas literally describes the Janus face of Rorty qua avant-garde intellectual and Rorty qua liberal democrat, respectively, as two perspectives, in which "Heidegger and Dewey are complementarily related to each other" (Jürgen Habermas, Ach, Europa (Frankfurt am Main: Suhrkamp, 2008), 21). Rorty himself employs a virtually analogous allegory in his famous article about "Trotsky [i.e. social hope] and the Wild Orchids [i.e. private, aesthetic self-development]" (cf. Rorty, Social Hope, 3-23).

27 Rorty, Social Hope, 202-3. 
At this place, this interpretation enables us to put forth two important as well as - once again — complementary claims, in which the intricate interplay between hope and irony is exhibited: firstly, (i) the private sphere rests on the esthetical hopefulness of existential irony. Secondly, (ii) the public sphere rests on the social hopefulness of epistemic irony. At first sight, at least the latter of these two sentences seems to be less than accurate. Can it be the very essence of the public sphere that it implies epistemological irony? Surely not, but these claims by no means pretend to represent any so-called essential features of private irony or-much less - of social hope. Rather, the two claims are presented in order to enable us to depict the two different ways in which the basic contingency of human knowledge must - in Rorty's opinion - be thought to "operate" in practice, namely: in the interest of private self-development and public responsibility, respectively. ${ }^{28}$ But not only this: we deliberately pick out the phenomena of irony and hope as our cornerstone concepts concerning the private and the public because this approach will allow us to unpack Rorty's entire philosophical project in a helpful manner. This approach, in other words, spells out that it is the default condition of human beings to strive for something without having "absolute" reasons as to why we strive for it, not to mention an understanding of how we can get it. Or to put the same point differently: we humans happen to be hopeful creatures under contingent (i.e. epistemologically "ironic") conditions. Privately, we can form any idiosyncratic self-image we wish for, in which case the "intellectual" ironism of extensive book-reading and trans-cultural analysis becomes not only tolerable but practically recommendable. ${ }^{29}$ Publicly, however, we should-if Rorty has any

28 Cf. ibid., 149. For two reasons, this very sentence is itself somewhat problematic. Rorty would be skeptical talking about contingency as basic in any traditionally philosophical sense of the term. Furthermore — and as has been argued for already—Rorty does not believe in any (meta)theory of theory, in which theory is treated as a discrete phenomenon outside of the (i.e. some) practical realm. Theory is always a theory in practice. And for Rorty, the differential nature of practice in its most common features is probably best described by means of Dewey's distinction between the private and the public (cf. Rorty, Irony, 83).

29 Rorty, Irony, 82-3 and Rorty, Cultural Politics, 89-105. Here, Rorty believes his defense of ironism to be in obvious opposition to Habermas' position. This is both right and wrong: Habermas does think — as opposed to Rorty—of an ideal public deliberation as more "rational" (or universal) than the idiosyncratic standards of private reasoning (cf. Jürgen Habermas, Der philosophische Diskurs der Moderne (Frankfurt am Main: Suhrkamp, 1988), 344 ff.). Habermas, however, does not have anything more principled against a certain limited domain, in which the "esthetics" of private "edification" can be unfolded (cf. Habermas, Ach, Europa, 35). 
say in the matter-much rather seek to balance the hopefulness of our will with the contingency of our finite existence in a somewhat different manner. The most crucial adjustment regarding the aforementioned balancing of hope and irony is put thus forward by Rorty himself in a declamatory comment on Derrida's reading of Marx:

What is most important about Marx [...] is that he reminds us about the possibility for justice. [...] [Justice] is his [i.e. Derrida's] name for the ultimate romantic hope, the Great Undeconstructable, the only thing we should not allow ourselves to be ironic about. ${ }^{30}$

Here, we must emphasize the importance of this quotation for the interpretation at hand. As it is, this short passage cites at least three of the prominent features of social hope: firstly, (i) it hinges on the modality of possibility. ${ }^{31}$ Secondly, (ii) social hope is not to be considered as a more rational endeavor than some romanticism-inspired aspiration to individual self-development (pace Habermas). On the contrary: it is itself "the ultimate romantic hope."32 Thirdly — and of considerable weight for the present reading-, (iii) social hope for justice is the one and only domain, within which the epistemic contingency (or irony) of liberal ironism should never allow itself to be existentially ironical in addition.

For one, these points can serve to clarify how Rorty can both decline "a single description which will suffice for both public and private purposes" and still refuse - in the name of irony - to draw a "distinction between a central, shared, obligatory portion and a peripheral, idiosyncratic, optional portion of one's final vocabulary." ${ }^{33}$ At first sight, these two assertions appear to imply a conspicuous contradictio in adjecto. It thus seems highly dubious whether Rorty can coherently refuse to hold private irony and social hope "in a single vision" and simultaneously pretend to repudiate any clear analytical distinction between the two ${ }^{34}$ as he does indeed seem to argue. At this point, fortunately, we have effectively acquired the conceptual tools to adequately dissolve Rorty's apparent enigma. As will be clear, the two statements are rather to be understood as mutually enforcing one another (qua fundamentally complementary). As such, they both rest on Rorty's refutation of the primacy

\footnotetext{
30 Rorty, Social Hope, 212, my italics.

31 That is, possibility as opposed to the pretention to necessary insights that marks the metaphysics of the tradition (cf. Rorty, Cultural Politics, $89 \mathrm{ff}$. and Rorty, Social Hope, 31).

32 Rorty, Cultural Politics, 27-42 and 105-120.

33 Rorty, Irony, 92 and Rorty, Social Hope, 3-23.

34 Cf. ibid., 7.
} 
of necessity, which traditional metaphysics and much of modern thinking venture to preserve. ${ }^{35}$ Consequently, the first claim disallows the Platonic fantasy of a meta-perspective sub species aeternitatis, from which the both impersonal and impractical Truth of everything can be stated once and for all. A standard version of such a vision could be the idea of the universality of public reason as opposed to the idiosyncrasy of private taste. From this point of view, we can and should hope to rid ourselves of the arbitrariness of the individual, so "that irony will no longer be necessary."36 In Rorty's contrasted view, however, irony is indispensable precisely because there is no super-vocabulary and, thus, no actual necessity sensu stricto to be found. And with this key insight we have already secured the core of the argument for Rorty's second refusal: we cannot possibly uphold any strong dichotomy between the "central" public debate and a "peripheral" private aspiration, respectively, exactly because we have no access to any super-perspective, from which we could determine some vocabularies as being more central than others. ${ }^{37}$

What is common to both the public and the private are the contingent hopes that guide us within both domains - and not some joint standard or inescapable hierarchy that (transcendental) philosophy will ever be able to decipher. What differs between them is the kind of "literature" and metaphors that will best assist our different purposes within the respective domains. ${ }^{38}$ In summa: as we lack necessity in our premises, we can conclude neither complete unity nor total disunity between the public and the private provinces of practice(s). And as ought to be clear at this point: what we share with each other in public hopes are not universal values, not to mention any universal "rationality" that can decide between our culturally imbedded vocabularies. In Rorty's own words, there is "no common human nature [...] [f] or all we share with all other humans is the same thing we share with all other animals - the ability

35 This is first and foremost the case for scientism as such but also holds for a good deal of contemporary analytical philosophers, in Rorty's opinion.

36 Rorty, Irony, 92 and Habermas, Diskurs der Moderne, $344 \mathrm{ff}$.

37 There appears to be an almost striking similarity between Rorty's critique of metaperspectives and Thomas Kuhn's critique of, for instance, Karl Popper's idea that there exist some kind of universally valid criteria of demarcation between science and pseudoscience (cf. Rorty, Social Hope, 175-189).

38 Rorty himself famously recommends Heidegger's "literature" for private and Dewey's for public purposes. Another rather elaborated example of an "edification"-division of labor is the potential self-development one can arrive at from reading Nabokov, on the one hand, as opposed to the responsiveness to other people's suffering that we can learn from Orwell, on the other (cf. Rorty, Irony, 141-188). 
to feel pain." ${ }^{39}$ And as Rorty's sees it, we should just not allow ourselves to be ironic about the hope to maturate our "susceptibility to pain and in particular to that special sort of pain which the brutes do not share with the humanshumiliation." ${ }^{40}$ No philosophical principle will ever force us to care for each other or convince the skeptic that he or she should care for others (cf. ibif.: $88 \mathrm{ff}$.). But it remains an actual possibility that we maturate our solidarity and social hope, nonetheless. And in Rorty's utopia, we should take up exactly this possibility in a both un-ironical and romantic manner-despite, that is, the indispensable (epistemic) contingency of the aspiration itself as well as its vocabulary.

In general, Rorty is noticeably satisfied with the modern epoch of European and North American history insofar as is represents "centuries of increasing public hope and private ironism." ${ }^{41}$ Although Rorty dismisses any attempt to understand the difference of hope and irony as an epistemic dichotomy of the necessity-variety, he still argues vehemently for a practical division of the two into-as we have coined it-(i) existential irony and (ii) social hope. Both of these phenomena synthesize epistemic contingency with romantic hopefulness, or in plainer (almost tautological) language: we ultimately want them because we simply happen to want them, not because we ultimately know of their necessary desirability let alone reasonableness.

We want to ask, however, whether the Rortarian division of labor between irony and hope really presents an attractive recommendation for how we should act, not to mention a convincing philosophical explanation for how we should think (about how we should act). It could seem, namely, as if Rorty is simply replacing the old dichotomy between necessary truth and contingent appearance with a new, (neo)pragmatic, one: namely the "firm distinction between the private and the public,"42 which for its part-as has been shown-implies a more elaborate distinction between "public hope and private ironism." ${ }^{33}$ In this regard, it is plainly misguided—or at the very best quite inaccurate-to simply conflate Rortarian ironism with epistemic skepticism

\footnotetext{
39 Rorty, Irony, 177, my italics and Rorty, Cultural Politics, 93.

40 Rorty, Irony, 92. As other interpreters have noticed, Rorty comes quite close to echoing John Stuart Mill in such places.

41 Ibid., 86 and Rorty, Social Hope, $252 \mathrm{ff}$.

42 Cf. e.g. Ibid., 43 and Rorty, Irony, 83.

43 Ibid., 86, my italics.
} 
tout court, as Michael Williams does. ${ }^{44}$ True enough, Rorty occasionally polemicizes skeptically against epistemic necessity. ${ }^{45}$ For the most part, importantly, Rorty nonetheless refuses to play the language game(s) of (classic as well as contemporary) epistemology. For Rorty, this discourse is irrelevant for our personal aspirations and common hopes to enter into epistemic debates, and-in his words- "what makes no difference in practice should make no difference to philosophy."46 What does matter, on his view, is instead practicing one's epistemic skepticism in a way that balances the ironical question 'who am I?' with the un-ironical question of 'who is suffering?' (and so caring or doing something about it). Furthermore, asking and answering questions of such blatant disparity calls for the maturation of "different" concepts, which for its part amounts to cultivating different vocabularies by reading different kinds of books. ${ }^{47}$ As such, Rorty has in common with the Pyrrhonist skepticism of his precursor Sextus Empiricus that the real point of his epistemic epoche is ultimately not the epistemic struggle itself as much as a practical transformation of one's ethico-existential way of living to which (goal) epistemic aporia is always merely a means. ${ }^{48}$

But even if we put aside the numerous misunderstandings of Rorty and thus stop accusing him (falsely) of being either a shallow relativist or a traditional metaphysician in disguise, do we still agree to his pragmatic division between hope and irony as the best way to cope with the contingent condition of humans? This question will present the guiding consideration for the rest of the present discussion.

44 Williams, "Epistemology," 210.

45 Rorty, "Response," $74 \mathrm{ff}$.

46 Rorty, Irony, ix, my italics.

47 Cf. e.g. Rorty, Social Hope, 144. Habermas characterizes the Rortarian belief in the connection between "displacing [verstellende] concepts" and a "jammed [verhakte] life" as Rorty's own "metaphysical premise." That we will most probably live badly if we think (i.e. use concepts and metaphors) badly is definitely Rorty's personal intuition. Yet, Rorty is not interested in a metaphysical argument about whether this belief rests on any "necessary connection" or not. When Rorty states that "our descriptions of nature, as well as of ourselves, will always be a function of our social needs" (Rorty, Irony, 48) the standard by which Rorty wants to be judged is not the correctness of the claim in itself, but its potential usefulness and hopefulness. Quite simply, does it help us or not? This question remains the only important "truth-criterion" and if Rorty has a metaphysics of his own, it is this latter idea-and not any necessary connection between thought and living.

48 Cf. Markus Gabriel, Antike und Moderne Skepsis - Zur Einführung (Dresden: Junius Verlag, 2008), 77-86 and Sextus Empiricus, Outlines of Pyrrhonism in Classics of Philosophy

- Third Edition, ed. Louis P. Pojman (Oxford: Oxford University Press, 2011), 362-77. 
In the following part of these considerations we will try to challenge Rorty's position on this matter via a reading of the Chicago-philosopher Jonathan Lear's still rather recent books on exactly these two phenomena, namely Radical hope - Ethics in the Face of Cultural Devastation (2006) and A Case for Irony (2011). Obviously, the following reflections do not pretend to present an exhaustive interpretation of Lear's position. Instead, I will attempt to synthesize the most important features of Lear's — at first sight — separate analysis of the two phenomena in order to subsequently problematize some implications of Rorty's division between the two.

It should be stressed that Lear agrees with Rorty on the level of quite a few important intuitions: for Lear as for Rorty, hope and irony are both phenomena that can only be understood (and adequately acted upon) if we realize that the modality of "possibility" is of more importance to them than its two rivaling modalities, i.e. logical (or metaphysical) "necessity" and empirical "actuality," respectively. ${ }^{49}$ As such, this concept of possibility must also be differentiated from possibility in terms of formal logic, not to mention "probability" in terms of empirically informed extrapolations. Lear himself articulates this intuition in the following manner:

A philosophical inquiry may rely on historical and anthropological accounts [...] but ultimately it wants to know not about actuality but about possibility [...] This [...] points to another difference between a philosophical inquiry and a regular empirical enquiry: ultimately, it is concerned with ought rather than is [...]. [Regarding] human possibility, philosophy, in its ethical dimension - wants to know: How ought we to live with it? ${ }^{50}$

A way to paraphrase this joint insight of Rorty and Lear would be the following claim: it is a mark of human existence that its reality transcends the mere materiality of its physicality as well as the inferential deductions of its logical thought. Or put differently: The real reality of human existence is - to a

49 The distinction between these three modalities of the understanding obviously draws thematically on Kant's "Table of Categories" in his Critique of Pure Reason (cf. Immanuel Kant, Kritik der reinen Vernunft (Hamburg: Felix Meiner Verlag, 1998), B106).

50 Jonathan Lear, Radical Hope - Ethics in the Face of Cultural Devastation (Cambridge: Harvard University Press, 2008), 8. I have had to cut a few things out of this quotation, as it is, because Lear is here specifically talking about the radical possibility of meaningless existence, which we will return to shortly. 
significant extent-the reality of its possibilities. ${ }^{51}$ Again we can neither understand this depiction as a purely formal characteristic nor as the mere presence of probabilistic reasoning in our lives. As it is, possibility is not primarily an epistemic category, through which detached, human subjects can understand the world. Rather, it is - in Rorty's terminology - a practical category (and reality) that conditions our lives. In another Rortarian paraphrase, possibility presents the adequate modal approach to a world, in which we strive to be able to deal with epistemological contingency without surrendering to either complete individual arbitrariness or cultural relativism. For Rorty, there is - in particular - a "moral potential inherent in our ability to communicate our needs and our hopes to others," ${ }^{2}$ and the maturation of sensitive (and shared) vocabularies can help us to actualize this potentiality. On this perspective, possibility (for private self-development and social justice) is effectively the practical expression for the fundamental hopefulness of our contingent being. Importantly, this relation also holds true for private ironism, insofar as ironism is nothing but one's personal play with the vast variety of possibilities for self-expression.

For Lear, irony and hope are two different "form[s] of existence,"53 through which human beings relate themselves to "life's possibilities." As the supernatant quotation illustrates, Lear thinks of the possibility-nature of our existence as expressing the "finite, erotic nature" of our "life with values," which we hope to become meaningful and-ultimately-happy. ${ }^{54}$ As should be obvious, all this is still very translatable into a through and through Rortarian vocabulary. ${ }^{55}$ What is interesting, however, is that Lear's analysis has some additional insights to offer; insights, as it is, that will forcefully challenge Rorty's decisive segregation of private irony and social hope. On this interpretation, I shall present Lear's position as a phenomenological counter-argument to Rorty's neo-pragmatic position. Phenomenology can mean a lot of different things but must here be thought of as a non-empirical account of a specific human "field of possibilities" (i.e. hope and irony) that is focused on both the "ethical"

51 Cf. Jonathan Lear, Happiness, Death, And the Remainder of Life - the Tanner Lectures on Human Values (Cambridge: Harvard University Press, 2000), 6.

$5^{2}$ Rorty, Irony, 204, my italics.

53 Cf. Lear, Radical Hope, 103, and Jonathan Lear, A Case for Irony - The Tanner Lectures on Human Values (Cambridge: Harvard University Press, 2011), 6.

54 Lear, Radical Hope, 49 and 123 and Lear, Happiness, 1.

55 As such, it will not make that much of a difference to replace "finite" with "contingent," "erotic" with "romantic," as well as "meaningful" with a "life worth living." 
and the "ontological dimension" of the given phenomenon. In Lear's own formulation: "if we are going to think about how to live with this possibility, we need to figure out what it is." ${ }^{56}$ As is obvious, Lear-unlike Rorty-does not shy away from understanding existential possibilities as ontologically real. In this way, Lear refuses to turn the fundamental finitude of human existence into a counterargument against any possible ontology. Lear does not mean to say that the sentence everything is actually possible is a valid ontological claim. Rather, he is arguing for the ontological reality of specific fields of possibility that can be adequately interpreted with phenomenological means. The argument is not at all as speculative as it may sound: it is simply a part of reality in its totality that some things are in fact possible for us humans. ${ }^{57}$ All in all, and in contrast to Rorty, Lear can meaningfully be read as subscribing to the Heideggerian idea of philosophy as a "phenomenological ontology" in which "possibility" stands higher than reality. This implies, namely, that its "description" must transcend the empirically given in its inclusion of possibility rather than actuality-configured spheres of meaning present in - for example-the (i) 'whys' of ethical (and existential) normativity as well as the (ii) 'hows' of the ontological structure..$^{58}$ Naturally, a phenomenological argument has to be able to exhibit its points in examples that - in one way or another-have an actual empirical content. A central claim of the phenomenologist is simply that the entire "content" (i.e. total meaning) of such examples cannot possibly be understood in terms of empirical facticity (cf. Heidegger's infamous depiction of "anxiety" in Sein und Zeit in which "nothing" really is the object of the

56 Lear, Radical Hope, 7 , my italics.

57 Markus Gabriel presents a forceful—and somewhat more sophisticated—argument for an analogous understanding of what he labels a "transcendental ontology." The pivotal insight in Gabriel's text is the thought "that our thoughts about the way world is are themselves a way the world is" (Markus Gabriel, Transcendental Ontology - Essays in German Idealism (New York: Bloomsbury, 2011), xii).

58 Cf. Lear, Radical Hope, 8, and Martin Heidegger, Sein und Zeit (Tübingen: Max Niemeyer Verlag, 2001), $38 \mathrm{ff}$. Although this cannot be comprehensively accounted for here, Lear's modus of phenomenological analysis may thus be said to take a Heideggerian rather than a Husserlian shape. This Heideggerian trait mutatis mutandis amounts to a rejection of Husserl's idea of phenomenology as the "pure description" of intentional acts (Edmund Husserl, Ideen zu einer reinen Phänomenologie und phänomenologischen Philosophie (Tübingen: Max Niemeyer Verlag, 2002), 113, Husserl's italics) in favor of an idea of meaning that—due to its constitutive unspecifiability, historicity and "instability"—-must be hermeneutically interpreted rather than "purely" described in its intentional "essence" (cf. Heidegger, Sein und Zeit, $34 \mathrm{ff}$. and Lear, Case for Irony, 22). As it is, Lear's study of the experience of radical hope and ironic disruption, respectively, should disclose this Heideggerian affinity to his approach. 
anxious experience). ${ }^{59}$ As we will render visible shortly, Lear ventures into analogously structured examples (of experiences). Nonetheless, we will leave this specific disagreement to be dealt with at another time. As we shall see, it is entirely possible to present Lear's position as a qualified critique of Rorty without entering into an ontological language game of the Heideggerian kind.

For Lear, meaning is always already handed over to us through the culture we inhabit. Lear presents this point in the Aristotelian language of virtues: some character traits are thought of as constitutive parts of a meaningful and happy life in any given culture and all of us base our everyday hopes on such culturally imbedded points of orientation. ${ }^{60}$ For the Rortarian, this is still fully acceptable. For Rorty, as we know, social hope is the joint aspiration within any such shared vocabulary and the recommended hope finds itself at home in a "liberal" vocabulary that maturates our responsiveness to other people's sufferings. ${ }^{61}$ Private irony, for its part, is the personally motivated step out of one's culturally inherited vocabularies in order to try new self-expressive potentials on for size. ${ }^{62}$ Lear's depiction, nevertheless, makes it clear that Rorty simply cannot account for the entire scope of the field of possibilities that these phenomena curiously "open" to our lives. Lear points first and foremost to two possible experiences (of possibility) within the phenomenological scope of hope and irony, which cannot adequately be made sense of through the Rortarian framework, namely (i) "radical hope" and (ii) "ironic disruption."63 Lear explains his notion of radical hope as follows:

Radical hope anticipates a good for which those who have the hope as yet lack the appropriate concepts with which to understand it [...] [in order] to establish what we might legitimately hope at a time when the sense of purpose and meaning that has been bequeathed to us by our culture has collapsed. ${ }^{64}$

True enough, Lear is concretely addressing the "textured historical context" of an Indian tribe, the Crow Nation, which has lost its normative standards of virtue and meaning (e.g. fighting the rivaling Sioux tribe and hunting the

\footnotetext{
59 Cf. Heidegger, Sein und Zeit, $184 \mathrm{ff}$.

60 Cf. e.g. Lear, Radical Hope, 17 and Aristotle, Nikomachische Ethik (Hamburg: Rowohlt Verlag, 2006), $1103 \mathrm{a} 15 \mathrm{ff}$.

61 Cf. Rorty, Social Hope, 202-3.

62 Lear, Radical Hope, $82 \mathrm{ff}$.

63 Cf. Lear, Radical Hope, 103 and Lear, Case for Irony, 15.

64 Lear, Radical Hope, 103-4, Lear's italics.
} 
buffaloes in a very particular way) after having been moved onto a reservation. ${ }^{65}$ Nonetheless, Lear is also very specific about being primarily concerned with this potential loss of meaning as a constitutive "vulnerability that we all share simply in virtue of being human." ${ }^{\prime 6} \mathrm{On}$ this reading, we ought to engage with radical hope as a possible experience for every existing human being. In our everyday lives and practices we can naturally experience disappointment and disorientation but in most cases such existential hiccups are to be understood as negative experiences within a culturally imbedded meaningfulness. As such, their negativity rests entirely on the fundamental positivity of existing normative points of orientation. To give a somewhat banal example: I am disappointed if an allegedly good friend is disloyal to me exactly because I positively value loyalty. For Rorty, this seems to be all there is to say, although certainly the scope of such hopes must be differentiated (cf. the very real difference between, e.g. loyalty, good meals and social justice, just to offer a few examples).

Admittedly, Rorty realizes that we cannot positively decide the exact content of a happy life that would be valid for everyone ${ }^{67} \mathrm{He}$ also definitely believes in the gradual changeability of the meaningfulness on which we base our hopeful aspirations. Otherwise, it simply would not make any sense to suggest that we encounter-let alone entertain - alternative as well as completely new vocabularies and literary metaphors in order to cultivate ourselves (both privately and socially, that is). ${ }^{68}$ Nonetheless, Rorty does not in any place seem to contemplate the challenge that meaning can be entirely lost for us (either personally or culturally), in which case our language-based endeavors will take form as a fundamental struggle to hold on to a kind of hope that somehow perseveres in spite of the "destruction of a way of life" by means of opening up to the very "possibility of new [...] possibilities."69 As such, radical hope is the possible experience of an event inside of language, where meaning is created - or comes to be-ex nihilo (i.e. for no reason inside of language) rather than acted (pragmatically) upon for reasons available to this or that competent player of this or that meaningful language game. Here, the expression

65 Cf. Ibid., $8 \mathrm{ff}$.

66 Ibid., my italics.

67 Cf. Rorty, Social Hope, 268. For Rorty, this normative "pluralism" is one he owes to Stuart Mill (cf. ibid.). Lear — for his part-virtually has an identical point in his intriguing book on Aristotle and Freud, Happiness, Death, And the Remainder of Life, in which Aristotelian "Eudaimonia" is said to be an "enigmatic signifier" which can never be fully determined in terms of any possible set of ethical virtues (cf. Lear, Happiness, 1-61).

68 Cf. Rorty, Cultural Politics, 89-131.

69 Lear, Radical Hope, 97-8, my italics. 
"ex nihilo" importantly does not mean to imply that there is nothing at all before language creates a meaningful horizon. Or in other words, Lear is not a nominalist constructivist. Rather, radical hope is about opening the possibility of a new meaning that was not there before, in a world that was there before but had - as it were-lost all meaning and had thus been rendered meaningless. In such a "world," be it manifest as a personal breakdown or a complete cultural collapse, there are not as much bad things happening as-radically so- -"nothing" happening. Things have simply stopped making sense at all.70 Against this completely disoriented as well as despairing depression of hopelessness, radical hope responds with a "daunting form of commitment: to a goodness in the world that transcends one's current ability to grasp what it is."71

The persuaded Rortarian might reply at least two things to Lear's position: (i) 'what's new'? We easily recognize the romantic potentiality of human language to-sometimes - carry us "beyond presently used language [...] [as well as] beyond the imagination of the present state of the world." ${ }^{72}$ Furthermore, (ii) she finds it thoroughly unappealing to accept Lear's idea about a particular experience of utter meaninglessness. Cultural devastation or personal trauma may be serious (existential) businesses, but phenomena like "anxiety," "hopelessness," and "humiliation" are not so much meaningless as they are meaningful in an undesirable way. ${ }^{73}$ Lear, as it is, would repudiate both of these objections, and for the following reason: meaning is a notion "meant" to explicate why we find some things worth doing (for either personal or social reasons). The "meaning" of an experience of the disappearance of the entire horizon of meaningfully being able to answer-let alone even cope with - the why-question is therefore nothing but an experience of meaninglessness itself. Radical hope, for its part, is thus the possible $r e$-installment of a meaningful why- "teleology," which transforms the destruction of a previous "telos into a teleological suspension of the ethical."74 Such a re-installment does not give us reason to do something particular (which Rorty can in fact explain for us)

$70 \quad$ Cf. ibid., $2 \mathrm{ff}$.

71 Ibid., 100, my italics.

72 Rorty, Social Hope, 161, my italics.

73 Cf. ibid., 90-1.

74 Ibid., 146. In a way, Lear's poetic paraphrase in Radical Hope of Kierkegaard's pseudonym Johannes de Silentio is a bit misguiding. On our interpretation it would be more accurate to speak of radical hope as the proto-teleological transcendence of meaninglessness into a new ethical (i.e. meaningful) world after the destruction of an old one. Allow me also to mention in passing here that Lear has worked with Bernard Williams (cf. Lear, Happiness, 158) whose infamous critique of utilitarianism famously gets under way with an accentuation of the importance of Nietzsche's insight that we must "possess our why of 
but is rather to be understood as the practical conditio sine qua non for doing anything (whatsoever) in the first place. As such, it is the why of all whys that radical hope re-opens to us. In summa: radical hope is the (possible) possibility of hope under hopeless circumstances, which retroactively-and somewhat paradoxically—reveals about the hopeless situation that the world was never really hopeless in its totality. And why not? Well, because the possibility of a hope that could not yet be grasped was always phenomenologically real in its very possibility. As an answer to the hypothetical Rortarian's initial counter-argument, this cannot be understood as some "romantic" potential to imagine "new" meanings that transcend the former ${ }^{75}$ but is instead the very reappearance of meaning as such in(side) the world, albeit still—in virtue of being radically hopeful - a meaning curiously bereft of any specific content whatsoever. Rortarian neo-pragmatism can deal with useful specifications of practical normativity as well as with re-imagining consensual meaning(s). It cannot, however, deal with radical hope as (potentially) happening when things have effectively stopped happening (qua meaningful) in which case "the temptation to despair is all but overwhelming."76

Let us sum up Lear's depiction of radical hope in a remark which can easily be read as positioning Lear in opposition to pragmatism: when our "final vocabulary" is not only maturated or ironically-in the Rortarian sense of the term—challenged, ${ }^{77}$ but has truly become "uninhabitable," then:

$[\mathrm{P}]$ ractical reason is deprived of important resources [...]. [P]ractical reason always aims toward what is useful, toward what is proper or appropriate behavior, or toward what is pleasant [...] But with the destruction of the telos, there was no conception of the good life to provide a larger context for the significance of one's acts. ${ }^{78}$

In such cases the meaning of pragmatism's social hopes and ironical variations simply depends on the phenomenological actuality of a radical hope that it is not itself capable of adequately conceptualizing. As such, the "usability" of pragmatism's numerous whys is utterly dependent on the existential ability of radical hope to open up the possibility for a fully undetermined but

life" (John Jamieson Carswell Smart and Bernhard Williams, Utilitarianism for and against (Cambridge: Cambridge University Press, 2007), 77).

75 Cf. Rorty, Social Hope, 161.

76 Lear, Radical Hope, 146, my italics.

77 Cf. Rorty, Irony, 73 .

78 Lear, Radical Hope, 57, my italics. 
qualitatively positive why in a place where all conventional whys have beensocially or personally (and never merely epistemically)—negated. Radical hope, to be brief, only seems to make sense well outside the Rortarian idea of practice. Hence it represents a serious challenge for any contemporary Rortarian as well as to any contemporary (neo)pragmatist.

Lear's philosophical study of hope effectively discloses some intriguing blind spots in Rorty's perspective on social hope. His later book on irony, A Case for Irony, however, presents the most serious challenge to Rorty's distinction between "public hope and private ironism."79 To delineate the essential features of this challenge will be the goal of the following section.

As it is, we will not take all of Lear's complex study into consideration but instead focus on the potential criticisms of Rorty's concept of irony which it implies. In A Case for Irony, Lear returns to his subscription to a rather Aristotelian understanding of the meaning and hopefulness of existence as constitutively tied up with certain "virtues" and "practical identities." ${ }^{\text {" } 0}$ Such an identity (e.g. being a teacher, a father, a car-driver, a student, etc.) is always to some extent dependent on a collective vocabulary, which allows its practitioner to express its purposefulness to him- or herself-as well as to others. To both Lear and Rorty, such an identity is susceptible to the "experience of irony." However, Lear's depiction of irony is crucially different from that of Rorty. Drawing on Kierkegaard's pseudonym Johannes Climacus (and in particular the latter's Concluding Unscientific Postscript), Lear provides phenomenological (as well as psychoanalytically informed) evidence for an actual experience of "ironic disruption," which he goes on to illustrate in the following manner:

[D]eveloping a capacity for ironic disruption may be a manifestation of seriousness about one's practical identity; it is a form of loyalty to it [...] It is constitutive of our life with the concepts with which we understand ourselves that they are subject to ironic disruption. ${ }^{81}$

But how can we make sense of this? Should we perhaps think of the "seriousness" of the ironic disruption in Lear's statement as an echoing paraphrase of Rorty's idea of the "ironist" as impressed by competing "final vocabularies" that

\footnotetext{
79 Rorty, Irony, 86.

8o Cf. Aristotle, Ethik, $1103 a 15$ ff. and Lear, Case for Irony, 31.

81 Lear, Case for Irony, 22, my italics.
} 
makes her continuingly doubt her own ones without believing that any of the possible vocabularies are "closer to reality" than alternative ones? ${ }^{82}$ Furthermore, is not Lear's claim about the constitutive subjection to ironic disruption in our existential cornerstone concepts a concise description of the constitutive contingency (and changeability) of the literary metaphors with which we understand ourselves in the Rortarian narrative? ${ }^{83}$

The short answer to both of these questions must be a clear 'no.' We will attempt to elucidate these abnegations in the following, but let us preliminarily re-cap the reasons as to why Rorty's understanding of hope did not add up to the phenomenon of radical hope as depicted by Lear. Briefly put, Rorty's vocabulary captures the nature of radical hope because the latter is an experience of the potential meaningfulness of a world "that transcends one's current ability to grasp what it is." 84 As such, radical hope designates the existential experience of a meaning, whose reality is "merely" the possibility of its possibility in a situation (i.e. world) in which each and every content-based specification of such a meaning has radically lost its meaning to us (in either a total sociocultural collapse or a personal depression, most paradigmatically). For Rorty, such formulations have to be treated as ontological nonsense insofar as, on his view, there simply cannot exist any meaning outside of the specific horizon of meaning in a specific language game. ${ }^{85}$ Unfortunately for the faithful Rortarian, radical hope can phenomenologically be exhibited as the experience of meaning in the shape of utter potentiality, which is exactly the experience of meaning itself in terms of a radically hopeful response in the face of vulnerability to the loss of meaning "that we all share in virtue of being human." 86

This brief recapitulation of Lear's claimed difference between meaning in itself and specified meaning is of assistance when we now seek to understand his unorthodox notion of irony. As it is, each practical identity implies "an aspiration or ideal" that is neither fully determinable (i.e. specifiable) nor anything existing beyond the practice of trying to live up to it. ${ }^{87}$ As was the case regarding radical hope, "ironic disruption" renders visible a constitutive gap between the necessary specificity of our practical endeavors, on the one hand,

\footnotetext{
82 Cf. e.g. Rorty, Irony, 73 .

83 Cf. Rorty, Social Hope, 71. In a through and through Nietzschean spirit, Rorty describes language as nothing but "a mobile army of metaphors" (cf. ibid.). On top of this, Rorty explicitly subscribes to a picture of the world as "our poem," wherefore the undesirability or un-usability of a given world can only by a "better poem" (cf. Rorty, Cultural Politics, 117).

84 Lear, Radical Hope, 103, my italics.

85 Cf. e.g. Rorty, Social Hope, xxiv and 51.

86 Lear, Radical Hope, 8.

87 Cf. Lear, Case for Irony, 11.
} 
and the impossibility of specifying once and for all what exactly the "aspiration or ideal" of any given practical identity amounts to, on the other. To give an example of Lear's prime intuition, one cannot try to be (i.e. become) oneself qua, for instance, 'student' without engaging oneself in certain concrete practices (e.g. studying, attending classes, passing exams, and so forth). However, one can also experience - via a so-called ironic disruption - the very ultimate indeterminacy of the question of how one becomes a good student by studying, attending classes, and passing exams (etc.) in the best possible way. ${ }^{88}$ In terms of modalities, it is a constitutive part of all practical identities that it is simply not possible - for non-psychotic persons - to believe that one is completely (or perfectly) fulfilling them in the best possible way. Instead, this experience should be converted into a capacity for ironic disruption that-for its partwill allow us to exist ironically.

But how is this any different from Rorty's vision of the ironist as someone who has "continuing doubts about the final vocabulary she currently uses?"89 It is crucially different, I would argue, insofar as Lear is simply not addressing the challenge to a meaning-complex in one final vocabulary which arises from another such vocabulary. Whereas Lear wants to stress—citing Kierkegaardthat ironic disruption "is a way of achieving a deeper understanding of - and ultimately a more earnest commitment to-what comes to emerge as one's final vocabulary," the Rortarian ironist merely "looks sideways over at other final vocabularies." 90

We must accentuate the dissimilarity between these notions of how irony works (or can work, at least) ${ }^{91}$ : Rorty's "private ironism" designates the creative interplay between rivaling and complementary vocabularies, through which the "great poem" of one vocabulary can—hopefully—be ironically challenged as well as esthetically optimized by the "still better poem" of another one. ${ }^{92}$ Lear, in contrast, points to the internal "ironism" of the immanent standard (or ideal) of one single vocabulary in which the ultimately transcendent (i.e. not-specifiable) nature of this very standard becomes visible. To exemplify the difference, it challenges my self-understanding as a student on the Rortarian model if I read a book about becoming an opera singer (rather than a student)

88 Cf. ibid., 10.

89 Rorty, Irony, 73 .

90 Lear, Case for Irony, 38, Lear's italics.

91 Both Lear and Rorty thus entertain rather positive understandings of the potential capacity of irony. For Rorty, as we know, irony is an epistemic condition as well as a kind of private excellence (cf. Rorty, Irony, 73 ff.). For Lear, the detachment of conventional ironism qua "undercutting any manifestation of seriousness" is a "derivative" form of the defining experience of ironic disruption, which he depicts (Lear, Case for Irony, 9). 
that excites my curiosity regarding further-and thus far unrealizedpossibilities for further self-expression and -investigation. Somewhat differently, the Lear-inspired-challenge to my practical identity as a student comes from the very ideal of being the best possible student I can possibly be, which - for its part-is contained within the phenomenological "field of possibility" of the practical identity itself. Importantly, this is simply not a contest between rivaling practices or vocabularies (e.g. 'student' versus 'opera singer' or 'blacksmith') as much as an internal tension or disruption inherent to the conceptual configuration of practical vocabularies themselves, or as Lear puts it in a polemic response to a (neo)Kantian critique of his position as formulated by Christine Korsgaard:

The experience of irony is a self-conscious experience of the disruption of the efficacy of practical thinking [...] In a practical context, this experience of ironic anxiety is one significant way in which we come to know that we do not know [...] The outward manifestation of this practical awareness is: I come to a halt. ${ }^{93}$

Unlike what was the case regarding the experience of radical hope, we do not "come to a halt" at occurrences of ironic disruption because meaningful things have completely stopped happening. ${ }^{94}$ Instead, we come to a halt in this experience because the possible full-scale realization of the ideal of an $a c$ tual practical identity can itself become both dubious and problematic. ${ }^{95}$ And what is more, in both radical hope and ironic disruption, we experience the

93 Lear, Case for Irony, 102, my italics. For Lear, Korsgaard subscribes to a much too Kantian picture of practical reasoning. Thus, Korsgaard can only think of irony in terms of reflectively distancing one from oneself. But the "breakdown of a structure" due to the unattainable actualization of its immanent ideal is simply "not another instance" of the practical structure (i.e. vocabulary) itself (cf. Lear, Case for Irony, 94-5 and Christine Korsgaard, "Self-Constitution and Irony" in Lear, Case for Irony, 75-84). As one will hopefully have noticed, Korsgaard's blind spot regarding the possibility for ironic disruption is completely analogous to Rorty's. As such, it simply echoes-in Kantian terms-Rorty's faulty belief that meaning is always meaning of a certain meaningful vocabulary (which can neither be thought to break down completely let alone immanently destabilize itself).

94 Cf. Lear, Radical Hope, $1-55$.

95 To this exact point, Lear offers a quite brilliant interpretation of Socrates' existential attitude of irony in Plato's Symposium. In this dialog, Alcibiades cannot make sense of why on earth Socrates is standing still for an entire night because of some irresolvable problem ("he just stood there trying to figure it out"). For Alcibiades, Socrates' (in)activity is nothing but plain stupidity. For Lear, in contrast, it is a both very personal and extremely potent manifestation of ironic disruption, wherefore "Socratic irony is thus an embrace of human open-endedness [...] [in] utter earnestness" (Lear, Case for Irony, 36 and Plato, 
reality of kinds of possibility that are effectively not accessible through Rorty's pragmatico-linguistic division between private ironism and public hope, namely (i) the very possibility for a possible meaning outside of any given vocabulary and (ii) the actuality of not-fully-realizable as well as specifiable ideals within all practical identities, which "shows that [and how any] practical identity has a certain instability built into it." ${ }^{\text {96 }}$ Rorty's perspective simply cannot account for these possibilities (i.e. the possibility of possible meaning and the reality of non-realizable idealization), wherefore he cannot make sense of any meaning beyond any meaningful vocabulary let alone a non-specifiable meaning of an ideal within one specific vocabulary.

Furthermore, and as should be clear, it is also obvious that both radical hope and ironic disruption are phenomena which cut across - and ultimately transcend-Rorty's Dewey-inspired division of the public and the private. As such, it applies to the meaningful aspirations of both the "esthetics" of personal self-development and the ethics of public hope that they can cease to make practical sense to us, in which case the capacity for radical hope's trust in the pure potentiality of meaning is called for. Both private inclinations and public hopes are also subject to a potential ironic disruption in Lear's sense of the word, as it is a characteristic of all concepts "with which we understand ourselves" that they constitutively imply practically embedded ideals we simply can never fully live up to. ${ }^{97}$ And importantly, this is not because these concepts (e.g. 'the good student' or 'the good father') are challenged by alternative ideals from rivaling vocabularies, but because the tension between their abstract ideality and their concrete specification is a constitutive trait of practical reality itself in its radical potentiality as well as its inherent vulnerability and instability.

In both Rorty and Lear's works, we encounter a convincing case for the ultimate finitude, contingency and possibility of human existence. On top of this, we learn not to think of the purely epistemological part of our contingent being as its most significant feature. Instead of looking at Rorty as an epistemic

Sokrates' forsvarstale, in Plato, Samlede verker i ny overscettelse - Bind I (Copenhagen: Gyldendal, 2010), 220c).

96 Lear, Case for Irony, 22.

97 Cf. ibid. 
"skeptic" or a downright "relativist," to his position as a philosophy of possibility and not least of practice. This displacement of focus turned our attention to the decisive distinction between "public hope and private ironism" 99 : a demarcation of the practical sphere that allows us to usefully differentiate the ironic "re-descriptions" of esthetic selfexpression from the (called-upon) un-ironical responsiveness to other people's suffering(s) with the latter encapsulating the "ultimate romantic hope" of our social life. ${ }^{100}$

Despite the (vast) range of meaningful phenomena that can effectively be accommodated by the Rortarian narrative, we have also brought to the fore a few that arguably cannot: for one, there is the sheer possibility of undetermined meaning as such when our meaning-constituting vocabularies (i.e. our world or our culture) have entirely "collapsed," which Lear labels the experience of radical hope. ${ }^{101}$ What is more, the "ironist" of Rortarian ironism ultimately possesses no language for the ironic disruption inherent to one of her final vocabularies (or practical identities) that Lear points to. In this kind of experience, the external disturbance of a possible, playful interplay between practical vocabularies is superseded by the internal instability of one such vocabulary ${ }^{102}$ - something the Rortarian perspective cannot make any real sense of. On this reading, Lear's phenomenological studies of hope and irony in effect recognize the finitude of our human being without adopting the onelevel account of Rorty's neo-pragmatic “vocabularism." Also, Lear makes manifest the abysmal character trait of finitude itself to the effect that the meaning of our everyday vocabularies is always vulnerable to meaningless disappearance (i.e. breakdown), reappearance (itself a meaningless experience of meaning's very possibility), as well as internal self-disturbance.

\section{Bibliography}

Aristotle. Nikomachische Ethik. Hamburg: Rowohlt Verlag, 2006.

Boghossian, Paul. Fear of knowledge - against Relativism and Constructivism. Oxford:

Clarendon Press, 2006.

98 Cf. Williams, "Epistemology," 210 and Paul Boghossian, The Fear of Knowledge - Against Relativism and Constructivism (Oxford: Clarendon Press, 2006), 58-95.

99 Rorty, Irony, 86.

100 Cf. Rorty, Social Hope, 212.

101 Cf. Lear, Radical Hope, 104.

102 Cf. Lear, Case for Irony, $9 \mathrm{ff}$. 
Brandom, Robert. Rorty and his Critics. Malden: Blackwell Publishing, 2008.

Conant, James. "Freedom, Cruelty, and Truth: Rorty versus Orwell." In Rorty and his Critics, edited by Robert Brandom, 191-212. Oxford: Blackwell Publishing, 2008.

Franzen, Jonathan. How to Be Alone. London: Fourth Estate, 2010.

Gabriel, Markus. Antike und moderne Skepsis - zur Einführung. Dresden:Junius Verlag, 2008.

Gabriel, Markus. Transcendental Ontology - Essays in German Idealism. New York: Bloomsbury, 2011.

Habermas, Jürgen. Der philosophische Diskurs der Moderne. Frankfurt am Main: Suhrkamp Verlag, 1988.

Habermas, Jürgen. Ach, Europa. Frankfurt am Main: Suhrkamp Verlag, 2008.

Hegel, Georg Wilhelm Friedrich. Grundlinien der Philosophie des Rechts. Frankfurt am Main: Suhrkamp, 1986.

Heidegger, Martin. Sein und Zeit. Tübingen: Max Niemeyer Verlag, 2001.

Husserl, Edmund. Ideen zu einer reinen Phänomenologie und phänomenologischen Philosophie. Tübingen: Max Niemeyer Verlag, 2002.

Kant, Immanuel. Kritik der reinen Vernunft. Hamburg: Felix Meiner Verlag, 1998.

Korsgaard, Christine. "Self-Constitution and Irony." In A Case for Irony - The Tanner Lectures on Human Values, edited by Jonathan Lear, 75-83: Cambridge: Harvard University Press, 2011.

Lear, Jonathan. Happiness, Death, and the Remainder of Life - The Tanner Lectures on Human Values. Cambridge: Harvard University Press, 2000.

Lear, Jonathan. Radical Hope - Ethics in the Face of Cultural Devastation. Cambridge: Harvard University Press, 2008.

Lear, Jonathan. A Case for Irony - The Tanner Lectures on Human Values. Cambridge: Harvard University Press, 2011.

Mann, Thomas. Betrachtungen eines Unpolitischen. Frankfurt am Main: Fischer Taschenbuch Verlag, 2009.

Meillassoux, Quentin. After Finitude - An Essay on the Necessity of Contingency. New York: Continuum, 2009.

Nietzsche, Friedrich. Also sprach Zarathustra. Köln: Anaconda Verlag, 2005.

Nietzsche, Friedrich. Zur Genealogie der Moral - Eine Streitschrift. Köln: Anaconda Verlag, 2006.

Plato. Staten. Copenhagen: Museum Tusculanums Forlag, 2003.

Plato. Sokrates' forsvarstale. Platon - Samlede verker i ny overscettelse - bind I, edited by Jørgen Mejer \& Christian Gorm Tortzen, 83-122. Copenhagen: Gyldendal, 2010.

Rorty, Richard. Philosophy and Social Hope. London: Penguin Books, 1999.

Rorty, Richard. "Sein, das verstanden werden kann, ist Sprache." In »Sein, das verstanden werden kann, ist Sprache«, edited by Rüdiger Bubner, 30-49. Frankfurt am Main: Suhrkamp, 2001. 
Rorty, Richard. Philosophy as Cultural Politics - Philosophical Papers, Volume 4. Cambridge: Cambridge University Press, 2007.

Rorty, Richard. Contingency, irony, and solidarity. Cambridge: Cambridge University Press, 2008a.

Rorty, Richard. "Response to Donald Davidson." in Rorty and his Critics, edited by Robert Brandom, 74-80. Oxford: Blackwell Publishing, 2008b.

Rorty, Richard. Philosophy and the Mirror of Nature. Princeton: Princeton University Pres, 2009.

Sextus Empiricus. (2011). Outlines of Pyrrhonism. In Classics of Philosophy - Third edition, edited by Louis P. Pojman, 361-78. Oxford: Oxford University Press, 2011.

Smart, John Jamieson Carswell \& Williams, Bernard. Utilitarianism for and against. Cambridge: Cambridge University Press, 2007.

Williams, Michael. "Epistemology and the Mirror of Nature." Rorty and his Critics, edited by Robert Brandom, 191-213. Oxford: Blackwell Publishing, 2008.

Žižek, Slavoj. First as Tragedy, then as Farce. London: Verso Books, 2009. 